\title{
Enhanced detection rate of typhoid fever among clinically suspected patients in a tertiary referral hospital in Dhaka, Bangladesh using nested polymerase chain reaction technology
}

\author{
Khan $\mathrm{S}^{1}$, Miah $\mathrm{MR}^{2}$, Khatun $\mathrm{S}^{3}$ \\ ${ }^{1}$ Assistant Professor, Department of Microbiology, Dr. Sirajul Islam Medical College, Dhaka, Bangladesh. \\ ${ }^{2}$ Professor, Department of Microbiology, Bangabandhu Sheikh Mujib Medical University, Dhaka, \\ Bangladesh ${ }^{3}$ Assistant Professor, Department of Microbiology, City Medical College, Gazipur, Bangladesh \\ Email:khan_shafinaz@yahoo.com
}

\begin{abstract}
A nested polymerase chain reaction (PCR) specific for Salmonella enterica subspecies enteric serovar Typhi was used for the detection of the pathogen in blood. This study was done during the period of March 2013 to February 2014. A total of 80 clinically suspected cases of typhoid fever were included in the study. Blood was collected from all participating individuals. Nested PCR targeting the flagellin gene (fliC) of Salmonella Typhi \& blood culture were done for each of the cases. The positivity rate of PCR $\&$ blood culture was $70 \% \& 20 \%$ respectively. The positivity rate of PCR was significantly higher than blood culture $(\mathrm{P}<0.05)$. With the nested PCR, $S$. Typhi DNAs were detected from blood specimens of $67.2 \%$ (43/64) patients among the suspected typhoid fever cases on the basis of clinical features but with negative cultures. We conclude that the PCR technique could be used as a novel diagnostic method of typhoid fever, particularly in culture-negative cases in an endemic country like Bangladesh.
\end{abstract}

Keywords: Typhoid fever, Nested polymerase chain reaction, Diagnosis.

\section{Introduction}

Typhoid fever is an infectious disease in developing countries like Bangladesh. It is estimated that more than 21 million people suffer from typhoid fever annually with more than 216,000 death attributed to the disease. ${ }^{1}$ Regions with high incidence of typhoid fever (> 100/1000.000 cases/year) include South Central Asia, South East Asia ${ }^{1}$ because safe drinking water $\&$ sanitation are inadequate in this region ${ }^{2}$. Three countries Pakistan, India, Bangladeshtogether account for about $85 \%$ of the world's typhoid cases.2 Laboratory diagnosis of typhoid fever is a major challenge still now. Though several serological tests such as Widal, Typhidot, Tubex are available, blood culture remains the gold standard for diagnosis of typhoid fever. Blood culture may take 2-7 days \& blood culture positivity wanes from $90 \%$ in the first week of fever to $25 \%$ after the third week. ${ }^{3}$ Failure of blood culture may occur due to some factors like low bacterial load, prior antibiotic uptake. ${ }^{4}$ Serological tests offer only indirect evidence of infection. Their interpretation may be difficult owing to past exposure to infection, immunization with vaccines (Ty2 1a vaccine, Vi vaccine) or early antibiotic treatment. ${ }^{4}$ Most of the physicians in Bangladesh have a tendency to prescribe antibiotics without micro biological confirmations. As a consequence, many strains of $S$. Typhi developed resistance to all the 3 primary antimicrobials-ampicillin, chloramphenical, trimethoprim -sulfamethoxazole. ${ }^{2}$ Quinolone resistance in $S$. Typhi has been recently described in various parts of Asia, possibly related to the widespread and indiscriminate use of quinolones. ${ }^{5}$ So, accurate diagnosis of typhoid fever is needed not only for etiological diagnosis \& clinical management but also for the prevention of development of multidrug resistant typhoid fever.

PCR has been emerged as a useful method for the diagnosis of many infectious diseases recently. The diagnostic value is significant specifically where there is a long cultivation period or low bacterial load. ${ }^{6}$ PCR could be a reliable test in the diagnosis \& management of typhoid fever. In case 
of typhoid fever, nested PCR is able to detect as few as 10 bacilli in clinical specimens. ${ }^{7}$ The purpose of the study was to optimize nested PCR in the laboratory and to assess whether the use of PCR could increase the detection rate of typhoid fever especially in case of culture negative cases due to prior antibiotic intake which is a common practice in Bangladesh.

\section{Materials and Methods}

The study was carried out in the Department of Microbiology, Bangabandhu Sheikh Mujib Medical University, Dhaka, between March 2013 to February 2014. A total of 80 blood samples from patients clinically suspected of having typhoid fever were collected for both blood culture \& PCR. The clinically suspected cases of typhoid fever were included based on continuous fever for more than 3 days, headache, anorexia, nausea, vomiting, abdominal discomfort with diarrhea, constipation, malaise, body ache. Patients with clinically suspected typhoid fever of both sexes, representing all age groups were included who came to Laboratory services of BSMMU for blood culture investigation, irrespective of their antibiotic treatment.

Blood culture by conventional method: Five $\mathrm{ml}$ of blood from each pediatric patient \& $7 \mathrm{ml}$ from each adult patient was drawn by vein puncture using disposable syringes with all aseptic precautions. The collected blood was ejected immediately into the conventional blood culture bottle, $3 \mathrm{ml}$ in pediatric bottle and $5 \mathrm{ml}$ in adult bottle. Two $\mathrm{ml}$ of blood was kept in a EDTA tube for PCR \& stored at $-20^{\circ} \mathrm{C}$ until DNA extraction. Inoculated blood culture bottle was incubated at $37^{\circ} \mathrm{C}$ aerobically. Blind subculture was done from the blood culture bottle after 24 hours, 48 hours, 72 hours of incubation on blood agar and McConkey agar media. The inoculated plates were incubated for 24 hours at $37^{\circ} \mathrm{C}$ aerobically. Culture negative bottles were reincubated for up to 7 days before discarded. Suspected colonies on subculture were identified as $S$. Typhi by colony morphology, Gram staining, biochemical tests. ${ }^{8}$

Extraction of DNA from blood sample: DNA extraction from blood was done by a method described earlier ${ }^{9}$ with some modifications. From previously collected $2 \mathrm{ml}$ blood in EDTA tube, one $\mathrm{ml}$ was taken in a sterile test tube and mixed with five ml RBC lysis buffer ( Qiagen, Germany) and incubated for 15 minutes at room temperature. Then it was centrifuged at $4,000 \mathrm{~g}$ for five $\min \&$ supernatant was discarded. One $\mathrm{ml} 0.2 \%$ Triton- $\mathrm{X}$ was added to the pellet $\&$ transferred into $1.5 \mathrm{ml}$ eppendrof tube, vortexed, and incubated for 10 minutes at room temperature, followed by centrifugation at $13,000 \mathrm{~g}$ for 10 minutes. The supernatant was discarded; the pellet was mixed with $0.2 \%$ Triton $\mathrm{X}-100$ again, vortexed\& incubated for 10 minutes at room temperature, followed by centrifugation at $13,000 \mathrm{~g}$ for 10 minutes.

The procedure was repeated until white pellet was formed. Then the pellet was washed with $1 \mathrm{ml}$ of nuclease-free water. Finally, the pellet was resuspended in $30 \mu \mathrm{l}$ of nuclease-free water, boiled for 10 minutes at $99^{\circ} \mathrm{C}$, then cooled in ice for 5 minutes and again boiled for 3 minutes followed by centrifugation for 3 minutes at $13,000 \mathrm{~g}$. Supernatant was taken in $1.5 \mathrm{ml}$ eppendrof tube. The suspension containing DNA was used as a template for PCR \& stored at $-20^{\circ} \mathrm{C}$ for use.

DNA extraction from culture: A single colony was suspended in $100 \mu \mathrm{l}$ of double- distilled water in $0.2 \mathrm{ml}$ PCR tube. Tube was placed in PCR machine, where incubated at $95^{\circ} \mathrm{C}$ for $10 \mathrm{~min}$, and cooled to $25^{\circ} \mathrm{C}$ (Prefixed). The PCR tube was then taken out \& centrifuged at $16,000 \mathrm{~g}$ for $30 \mathrm{sec} \&$ clear supernatant was used as the template for $\mathrm{PCR}^{10}$ which was diluted at 1: 200 in doubledistilled water, and the diluted template was stored at $-20^{\circ} \mathrm{C}$ which was used as a positive control later.

Primers: Primers which target the flagellin gene of $S$ Typhi designed by Song et al were used for PCR. Primers synthesized on Jena Bioscience, Germany. Oligonucleotides ST1 (5'- ACT GCT AAA ACC ACT ACT-3') and ST2 (5'TTAACGCAGTAAAGAGAG-3') were used for regular PCR to amplify a $458 \mathrm{bp}$ fragment. For nested PCR, oligonucleotides ST3 (5'- ACT GCT AAA ACC ACT ACT -3') and ST4 (5'TGGAGACTTCGGTCGCGTAG-3') were used to amplify a 343 bp fragment.

Application in thermal cycler: For regular PCR, $10 \mu \mathrm{L}$ master buffer contained PCR buffer, $\mathrm{MgCl} 2$, deoxynucleoside triphosphate obtained 
from Texas Biogene Inc. USA, $1.5 \mu \mathrm{l}$ of each primer, $0.2 \mu \mathrm{l}$ of Taq polymease, $2 \mu \mathrm{L}$ of template were taken in a $0.2 \mathrm{ml}$ PCR tube. Using a thermal cycler (Applied biosystem 2720), the reaction mixture was subjected to 40 cycles of 1 minute each at $94^{\circ} \mathrm{C}, 55^{\circ} \mathrm{C}$ and $72^{\circ} \mathrm{C}$, followed by heating at $72^{\circ} \mathrm{C}$ for 10 minutes. For nested PCR, 1:5 dilution of amplified product of first round was used as template. The tube was kept in thermal cycler and allowed to run for 30 cycles as well as the same protocol of the first round PCR.

Detection of PCR product: Following nested $\mathrm{PCR}, 10 \mu \mathrm{L}$ of amplified product was fractionated electrophoretically in $2 \%$ agarose gel containing $0.5 \mu \mathrm{g}$ of ethidium bromide per ml. A positive control representing diluted suspension containing DNA (1:200) from isolate of $S$ Typhi, and a negative control without any DNA were also included in each lot. A 100bp DNA ladder was included to determine the size of the fragments.

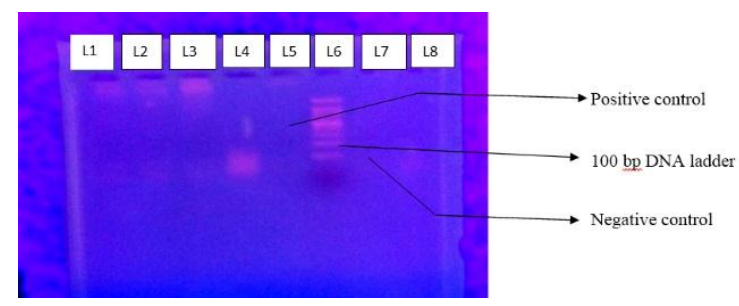

Fig. 1: Amplification of $458 \mathrm{bp}$ product of flagellin gene (fliC-d) of S. Typhi after first round of PCR (Lane 1,2,3,4,8: Samples from suspected typhoid fever cases; Lane 5: Positive control containing diluted suspension of S.Typhi DNA; Lane 6: 100 bp DNA ladder; Lane 7: Negative control).

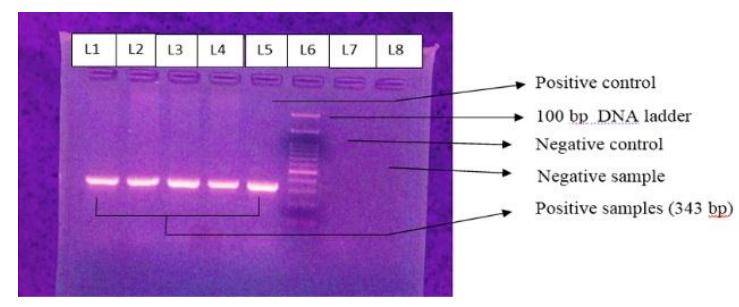

Fig. 2: Amplification of 343 bp product of flagellin gene (fliC-d) of S. Typhi after second round of PCR (Nested PCR) (Lane 1,2,3,4 : Positive samples; Lane 5: Positive control containing diluted suspension of S.Typhi DNA; Lane 6: 100 bp DNA ladder; Lane 7: Negative control. Lane 8: Negative sample).

Statistical analysis: After collection of all data were checked, edited and analyzed by using computer based SPSS (Statistical Package of Social Science) software, $\mathrm{p}$ value $<0.05$ was taken as minimal level of significance. Diagnostic statistics, viz. sensitivity, specificity, positive \& negative predictive values \& likelihood ratios (LR+, LR-) were calculated taking blood culture as a gold standard.

\section{Result}

From the 80 clinically suspected cases, 16 (20\%) cases were blood culture positive for Salmonella species and the remaining $64(80 \%)$ cases were negative for Salmonella \& other organisms. Among 80 blood samples subjected to PCR from the suspected cases, 56 (70\%) showed positive results for $S$. Typhi. Among the total 16 Salmonella isolates, $13(81.3 \%)$ were $S$. Typhi \& $3(18.7 \%)$ were $S$. Paratyphi A.

To calculate the diagnostic validity of PCR method for the diagnosis of typhoid fever taking blood culture as a gold standard, it was found that $13(16.3 \%)$ cases which were blood culture positive for $S$ Typhi were also PCR positive (Here, $3 S$ Paratyphi A cases were excluded from analysis). These 13 cases were considered as true positive cases. Among the culture negative cases, $43(53.8 \%)$ cases were positive by PCR method. Therefore, these cases were regarded as false positive cases. The remaining 24(30\%) culture negative cases were also negative by PCR method and these cases were considered as true negative cases. After calculation it was found that the sensitivity, specificity, positive \& negative predictive values, positive $\&$ negative likelihood ratio of PCR were 100\%, 35.8\%, 23.2\%, 100\%, $1.6 \& 0$ respectively. (Table I).

Table I: Validity of PCR method for the diagnosis of typhoid fever $(n=80)$

\begin{tabular}{cccc}
\hline \multirow{2}{*}{ PCR results } & \multicolumn{2}{c}{ Blood culture results } & Total \\
\cline { 2 - 3 } & $\begin{array}{c}\text { Positive } \\
\text { no }(\%)\end{array}$ & $\begin{array}{c}\text { Negative } \\
\text { no }(\%)\end{array}$ & \\
\hline Positive & $13(16.3)$ & $43(53.8)$ & $56(70)$ \\
Negative & $0(0.0)$ & $24(30)$ & $24(30)$ \\
\hline Total & $13(16.3)$ & $67(83.8)$ & $80(100)$ \\
\hline
\end{tabular}

By observing the relationship between results of PCR \& blood culture with duration of fever, it was found that among 36 cases who came with 3-7 days of fever, 27 (75\%) cases were detected by PCR \& $10(27.8 \%)$ cases were detected by blood culture. Among 34 cases who came with 7-10 days of fever, $23(67.6 \%)$ cases were detected by PCR whereas 3(8.8\%) were blood culture positive 
for $S$. Typhi. Out of 10 cases who came with fever more than 10 days, $6(60 \%)$ were detected by PCR but none was positive for blood culture (Table-II).

Table II: Rate of S. Typhi detection by PCR \& Blood culture method among the suspected typhoid fever cases in relation to duration of fever

\begin{tabular}{cccc}
\hline $\begin{array}{c}\text { Duration of } \\
\text { fever } \\
\text { (Days) }\end{array}$ & $\begin{array}{c}\text { No. of } \\
\text { cases }\end{array}$ & $\begin{array}{c}\text { Detection by } \\
\text { PCR } \\
\text { no. }(\%)\end{array}$ & $\begin{array}{c}\text { Detection by } \\
\text { blood culture } \\
\text { no. }(\%)\end{array}$ \\
\hline $3-7$ & 36 & $27(75)$ & $10(27.8)$ \\
$7-10$ & 34 & $23(67.6)$ & $3(8.8)$ \\
$>10$ & 10 & $6(60)$ & $0(0.0)$ \\
\hline Total & 80 & $56(70)$ & $13(16.3)^{*}$ \\
\hline *Blood culture positive for $S$. Typhi were only included
\end{tabular}

Considering the relationship of antibiotic usage with the results of blood culture \& PCR among the suspected cases it was found that none of the blood culture positive cases had taken antibiotic prior to sample collection. Majority of the culture negative cases gave history of taking different antibiotics for variable periods (Table-III).

Table III: Results of blood culture \& PCR in relation to history of antibiotic intake.

\begin{tabular}{|c|c|c|c|c|c|}
\hline \multicolumn{3}{|c|}{ History of antibiotic intake } & \multirow[b]{2}{*}{$\begin{array}{l}\text { No. of } \\
\text { cases }\end{array}$} & \multirow{2}{*}{$\begin{array}{c}\text { No. }(\%) \\
\text { of Blood } \\
\text { culture } \\
\text { positive } \\
\text { cases }\end{array}$} & \multirow[b]{2}{*}{$\begin{array}{c}\text { No. }(\%) \\
\text { of PCR } \\
\text { positive } \\
\text { cases }\end{array}$} \\
\hline Antibiotic & $\begin{array}{c}\text { Dosage } \\
\text { schedule }\end{array}$ & $\begin{array}{c}\text { Duration } \\
\text { of intake } \\
\text { (Days) }\end{array}$ & & & \\
\hline Ciprofloxacin & $\begin{array}{l}500 \mathrm{mg} \\
\text { twice } \\
\text { daily }\end{array}$ & $3-6$ & 12 & 0 & $\begin{array}{c}11(91 . \\
7)\end{array}$ \\
\hline Levofloxacin & $\begin{array}{c}500 \mathrm{mg} \\
\text { single }\end{array}$ & $3-5$ & 8 & 0 & $5(62.5)$ \\
\hline Cefradine & $\begin{array}{l}250 \mathrm{mg} \\
\text { Every } 6 \\
\text { hourly }\end{array}$ & $2-5$ & 11 & 0 & $6(54.5)$ \\
\hline Azithromycin & $\begin{array}{c}500 \mathrm{mg} \\
\text { single }\end{array}$ & $3-5$ & 7 & 0 & $6(85.7)$ \\
\hline Cotrimoxazole & $\begin{array}{c}1 \text { double } \\
\text { strength } \\
\text { tablet } \\
\text { twice } \\
\text { daily }\end{array}$ & $2-3$ & 5 & 0 & $3(60)$ \\
\hline Cefixime & $\begin{array}{c}200 \mathrm{mg} \\
\text { single }\end{array}$ & $2-4$ & 7 & 0 & $4(57.1)$ \\
\hline
\end{tabular}

*Fourteen cases who were culture negative had taken some kind of drugs but could not mention the names

\section{Discussion}

The symptoms \& signs of typhoid fever are nonspecific \& may mimic the symptoms of other fevers including dengue, malaria, hepatitis in typhoid endemic regions ${ }^{11}$. Culture provide definite proof of typhoid fever. In present study, 16 out of 80 cases had positive blood culture for Salmonella species and an additional 64 cases were diagnosed as having typhoid fever based on clinical signs and symptoms. The reported positivity rate of blood culture is $14 \%-16.7 \%$ in different studies done in Bangladesh. ${ }^{12-14}$ The low culture-positivity rate of blood culture for $S$. Typhi in patients diagnosed clinically as suffering from typhoid fever in the community prompted us to look for an additional or alternative diagnostic tool. PCR is another test that has shown high sensitivity \& specificity for diagnosis of typhoid fever in several studies. Several investigators have used different genes like flagellin gene, ${ }^{7}$ viaB region $^{15}$ and no single method has yet been standardized for use in the clinical setting. In this study flagellin gene was used to detect $S$. Typhi by PCR, because the flagellin gene of $S$. Typhi has unique nucleotide sequences in hypervariable region VI which are different from those sequences in other strains of Salmonella. ${ }^{7}$ Most of the studies used flagellin gene as a molecular technique for detection of S.Typhi in clinical specimens. ${ }^{7,16-19}$ The alternative method where $\mathrm{ViaB}$ region is targeted can give false positive result due to the presence of this sequence in $S$. Paratyphi C. ${ }^{15}$

The sensitivity of PCR assay depends on target gene, primer sequence, type of DNA extraction procedures and type of PCR techniques ${ }^{20}$. Several different protocols were considered \& that described by Nagarajan et al. ${ }^{9}$ with some modification was selected. In this study, out of 80 suspected typhoid fever cases, flagellin gene $(\mathrm{fliC}$ d) was detected by PCR in $56(70 \%)$ cases which corresponds with the result of similar study done in Bangladesh where PCR was positive in $88.7 \%$ of suspected typhoid fever cases ${ }^{21}$. The reported positivity rate of PCR is $65 \%-71.9 \%$ in different studies $^{16,22}$.

Application of a nested PCR amplifying a segment of flagellin gene of $S$. Typhi in whole blood samples showed positive results in $67.2 \%$ (43/64) culture negative clinically diagnosed typhoid fever cases. The finding of positive PCR results for blood samples from culture-negative typhoid fever cases is consistent with the previous observations, which showed that PCR for typhoid fever might have higher sensitivities than blood culture $16,18,19,23$. PCR was found to be negative in 3 culture positive cases. These 3 cases were culture positive for $S$. Paratyphi A. This indicates that this PCR protocol is highly specific for $S$. Typhi.

In this study, PCR could diagnose $75 \%$ of the cases during the initial 7 days of illness. Only 
$27.8 \%$ of the blood cultures grew $S$. Typhi in this period. For patients presenting with fever for 7-10 days duration, PCR could detect $67.6 \%$ of the cases as compared to $8.8 \%$ positive blood culture cases. Even in the later stages of the diseases, $60 \%$ of cases were detected by PCR but no case was blood culture positive. Similar study done in India reported PCR could diagnose $76.2 \%$ cases during initial 1-5 days of illness, $61.9 \%$ during 6-10 days of illness and $53.8 \%$ during later stage of illness. ${ }^{23}$ But they did not compare PCR results with blood culture results. This indicates that PCR can detect maximum number of typhoid fever cases in comparison to blood culture during any stage of disease. These values, though statistically insignificant, show that rate of $S$. Typhi detection by PCR decreases with increased duration of fever. The possible explanation might be intake of antibiotics in most of the cases. As a result the bacteria within blood might be dead due to the effect of antibiotics. The dead bacteria were subsequently cleared by the immune system which could not be detected by PCR.

Statistical analysis showed higher sensitivity \& lower specificity. Despite these observations, it is possible to comment that PCR rarely miss the individual with typhoid fever. Again PCR can be used to exclude typhoid, as typhoid fever is one of the important causes of PUO (Pyrexia of unknown origin). From the positive \& negative likelihood ratios it was found that this test had a diagnostic value.

Conclusion: According to the findings of this study it can be concluded that PCR assay can detect maximum number of typhoid fever cases mainly those who have history of prior antibiotic intake \& those with problematic \& varying clinical manifestations. Therefore, PCR assay is important for the reduction of mortality, morbidity\& acquisition of the carrier state which helps in reducing transmission of typhoid fever.

\section{References}

1. Crump JA, Mintz LS. The global burden of typhoid fever. Bull World Health Organ 2004; 82: 346-53.

2. Maurice J. A first step in bringing typhoid fever out of the closet. The Lancet 2012; 379 (9817): 699 700 .

3. Antony JT, Patwary AK, Anand VK, Pillai PK, Aneja $\mathrm{S}$, Sharma D. Duodenal string test in typhoid fever. Indian Paediatric1993; 30:643-647.
4. Das JC. Laboratory investigation of enteric fever in children: an update. JCMCTA 2007; 18(2):37-42.

5. Renuka K, Sood S, Das BK and Kapil A. High-level ciprofloxacin resistance in Salmonella enterica serotype Typhi in India. J Med Microbiol 2005; 54(10): 999-1000.

6. Kumar A, Arora V, Bashamboo A, Ali S. Detection of Salmonella Typhi by polymerase chain reaction: implications in diagnosis of typhoid fever. Infect. Genetics Evol. 2002; 2: 107-110.

7. Song JH, Cho H, Park MY, Na DS, Moon HB, Pai CH. Detection of Salmonella Typhiin the blood of patients with typhoid fever by polymerase chain reaction. J. Clin. Microbial. 1993 ; 31:1439-1443.

8. Cheesbrough M (ed) 2006. District Laboratory Practice in Tropical Countries, $2^{\text {nd }}$ ed. Cambridge: Cambridge University Press. Chp: 7, pp. 121-125.

9. Nagarajan AG, Karnam G, LahiriAet al. Reliable means of diagnosis and serovar determination of blood borne salmonella strains. Quick PCR Amplification of Unique Genomic Loci by Novel primer sets. Journal of Clinical Microbiology 2009; 47(8):2435-2441.

10. Levy H, Diallo S, Tennant SM et al. PCR method to identify Salmonella enteric Serovars Typhi, Paratyphi A, and Paratyphi B among Salmonella isolates from the blood of patients with clinical enteric fever. J. Clin. Microbiol. 2008; 46(5):1861.

11. Ismail A. New advances in the diagnosis of typhoid and detection of typhoid carriers. Malaysian Journal of Medical Sciences 2000; 7(2):3-8.

12. Begum Z. Comparison among the different diagnostic procedures for early \& rapid diagnosis of typhoid fever, M.Phil thesis (2008), Dhaka University. (Online) Available at: http://www.mmc.gov.bd/downloadable\%20file/Rapi d\%20Diagnosis\%20of\%20Typhoid\%20Fever\%20by $\% 20$ Dr.\%20Johra\%20Begum.pdf. (Accesed on 03.05.2013)

13. Hossain S. Comparative study of widal test and Dot EIA for early serodiagnosis of typhoid fever, M. Phil. Thesis (2001), B.S.M.M.U.

14. Sultana S .Comparison of different test methods including polymerase chain reaction for early and reliable diagnosis of typhoid fever, M.Phil. Thesis (2012b), B.S.M.M.U. (Online) Available at: http://www.mmc.gov.bd/downloadable\%20file/typh oid\%20fever\%20by\%20PCR\%20by\%20Dr.\%20Safi a\%202012.pdf. (Accessed on 05.04.2013).

15. Hashimoto Y, Itho Y, Fujinaga $Y$ et al.Development of nested PCR based on the ViaB sequence to detect Salmonella typhi.J. Clin. Microbiol. 1995; 33(3): 775 . 
16. Haque A, Ahmed J, Qureshi JA. Early detection of typhoid by polymerase chain reaction. Ann. Saudi Med. 1999; 19: 337-340.

17. Hatta M, Smits HL. Detection of Salmonella Typhiby nested PCR in blood, urine and stool samples. Am. J. Trop. Med. Hyg. 2007; 76:139-143.

18. Massi MN, Shirakawa T, Gotoh A et al. Rapid diagnosis of typhoid fever by PCR assay using one pair of primers from flagellin gene of Salmonella Typhi. J. Infect. Chemother. 2003; 23: 233-237.

19. Prakash P, Mishra OP, Singh AK et al. Evaluation of nested PCR in diagnosis of typhoid fever. J Clin. Microbiol2005; 43: 431-432.
20. Hirose K, Ichiro JK, Nakajima $\mathrm{H}$ et al. Selective amplification of tyv ( $\mathrm{rbE}$ ), Prt (RfbS), Via B and fliC genes by multiplex PCR for identification of Salmonella enteric serovars Typhi \& Paratyphi A . J Clin Microbiol. 2002; 43 (1): 431-432.

21. Sultana S, Hossain MA, Alam MA et al. Nested polymerase reaction for the early diagnosis of typhoid fever.Mymensingh Med J.2012; 21(1):21-7.

22. Khan S, Harish BN, Menezes GA, Acharya NS and Parija SC. Early diagnosis of typhoid fever by nested PCR for flagellin gene of Salmonella enteric serovar Typhi. Indian J Med Res. 2012; 136(5): 850-854.

23. Ambati SR, Nath G, Das BK. Diagnosis of typhoid fever by polymerase chain reaction. Indian J. Pediatr. 2007; 74, 909-913. 